\title{
Pemberdayaan Masyarakat Pesantren tentang Sel Surya untuk Fasilitas Listrik di Desa Sekarwangi, Cibadak, Sukabumi Jawa Barat
}

\author{
Donny Montreano ${ }^{1 *}$, Mohammad Rachman Waluyo ${ }^{2}$, Reda Rizal ${ }^{3}$ \\ 1Program Studi Teknik Industri Fakultas Teknik, Universitas Pembangunan Nasional “Veteran" Jakarta
}

\section{A R T I C L E I N F O}

\section{Article history:}

Received 19 August 2018 Received in revised form 19 September 2018 Accepted 20 Oktober 2018

Available online 24

November 2018

\section{Kata Kunci:}

Elektrifikasi, Energi

Alternatif, Panel Surya

Keywords:

Electrification, Alternative

Energy, Solar Panels

\begin{abstract}
A B S T R A K
Pemerintah menargetkan 10.300 desa teraliri listrik pada 2019. Pada 2019, peningkatan rasio elektrifikasi nasional ditargetkan menjadi 97 persen. Melalui Kementerian Energi dan Sumber Daya Mineral (ESDM), meluncurkan Program Indonesia Terang (PIT) dalam rangka memenuhi target peningkatan rasio elektrifikasi nasional dari 85 persen pada tahun 2015 menjadi 97 persen di tahun 2019. PIT juga menjadi bagian dari target pemerintah yang menyediakan akses penerangan bagi masyarakat Indonesia secara merata melalui pembangunan pembangkit $35.000 \mathrm{MW}$. Dalam rilis pers Kementerian ESDM pada 28 Februari 2016, disebutkan bahwa hingga saat ini, masih ada 12.659 desa tertinggal yang belum memperoleh akses listrik dari jaringan Perusahaan Listrik Negara (PLN), bahkan 2.519 desa diantaranya belum terlistriki sama sekali. Desa-desa ini sebagian besar tersebar di Provinsi Papua dan di kawasan Indonesia Timur lainnya. Populasi penduduk rata-rata sedikit dengan tingkat kepadatan yang rendah, akibatnya membangun jaringan listrik menjadi sangat mahal dan membuat hitung-hitungan ekonomi menjadi rugi. Pemerintah perlu memberikan perhatian lebih khusus kepada masyarakat di desa-desa tertinggal ini supaya mereka dapat segera terlayani listrik, tanpa kebijakan dan aksi yang berpihak, desa-desa tersebut mustahil bisa mengakses listrik sesuai target yang telah dicanangkan.
\end{abstract}

\section{A B S T R A C T}

The government targets 10,300 villages to be electrified by 2019. In 2019, an increase in the national electrification ratio is targeted at 97 percent. Through the Ministry of Energy and Mineral Resources (ESDM), launched the Bright Indonesia Program (PIT) in order to meet the target of increasing the national electrification ratio from 85 percent in 2015 to 97 percent in 2019. PIT is also part of the government's target to provide lighting access for the people of Indonesia evenly through the construction of $35,000 \mathrm{MW}$ power plants. In the press release of the Ministry of Energy and Mineral Resources on February 28, 2016, it was stated that up to now, there are still 12,659 underdeveloped villages that have not yet obtained access to electricity from the National Electricity Company (PLN) network, even 2,519 villages have not been completely electrified. These villages are mostly spread in the Papua Province and in other Eastern Indonesia regions. The population of the population is on average a little with a low density level, consequently building an electricity network is very expensive and makes economic calculations become a loss. The government needs to pay more special attention to the people in these underdeveloped villages so that they can be immediately served by electricity, without impartial policies and actions, these villages are unlikely to be able to access electricity according to the planned target.

\footnotetext{
* Corresponding author.

E-mail addresses: montreano@gmail.com (Donny Montreano),
} 


\section{Pendahuluan}

Desa Cibadak adalah satu dari 10 desa di kabupaten Sukabumi yang memiliki luasan 63.435,41 Ha, berpenghuni 99.877 jiwa. Memiliki kepadatan 1064 jiwa / km2. Sebagian penduduk Cibadak adalah petani. Dari data monografi Kecamatan Cibadak tercatat 7.405 orang atau 7,41\% penduduk Kecamatan Cibadak bekerja di sektor Pertanian. Lembaga Pendidikan Ketrampilan Sulamut Taufik berada di bawah Yayasan Sulamut Taufik bertujuan memberi bekal ketrampilan peserta didik di lembaga pendidikan formal yang bernaung di bawah yayasan yaitu PAUD, SD, SMP, SMA, MTs, MA dan Pondok Pesantren sehingga siswa tidak hanya memiliki pengetahuan tapi juga ketrampilan yang dapat bermanfaat bagi masa depan siswa pada masa yang akan datang.

Yayasan Sulamut Taufik berkomitmen untuk meningkatkan kualiatas sumber daya manusia dan memberi kesempatan kepada semua lapisan masyarakat terutama lapisan bawah agar memiliki peluang yang sama untuk memperoleh pendidikan dan pengajaran sebagaimana yang diamanahkan oleh pembukaan UUD 1945 yaitu mencerdaskan kehidupan bangsa. Selain sebagai bekal ketrampilan kegiatan tersebut juga diharapkan pada masa yang akan datang dapat menjadi salah satu sumber penghasilan lembaga dan menyerap tenaga kerja serta meningkatkan kesejahteraan khususnya pengurus yayasan umumnya masyarakat sekitar yayasan yang mayoritas adalah alumni dan orang tua siswa. Namun demikian untuk mewujudkan cita-cita tersebut mitra masih memiliki berbagai kendala diantaranya: (1)

Keuangan yang minim karena siswa tidak dikenakan biaya sehingga operasional hanya mengandalkan Bantuan Operasional Sekolah BOS dan swadaya pengurus Yayasan, (2) Letak Geografis Yayasan yang agak terpencil dan jauh dari jalan raya $(1 \mathrm{~km}$ jalan setapak) Sehingga menyulitkan akomodasi dan transportasi orang maupun barang, (3) Jaringan Listrik yang belum sampai ke lokasi desa sehingga kekurangan daya listrik untuk menopang kegiatan yang membutuhkan pasokan listrik. Hal tersebut dikarenakan pihak PLN yang membebani biaya tambahan pada pihak mitra untuk membangun jaringan baru dan gardu baru, (4) Peralatan pendidikan yang kurang memadai baik dari segi kualitas maupun kuantitas sehingga menjadi salah satu kendala dalam menunjang proses dan hasil belajar dan latihan ketrampilan serta hasil produksi sesuai standar yang diharapkan.

Program pengabdian kepada masyarakat ini berfokus pada permasalahan infrastruktur khususnya ketersediaan tenaga listrik. Minimnya ketersediaan tersebut merembet ke permasalahan penerangan akses jalan raya ke lokasi mitra sasaran. Akses jalan telah diusahakan menerima bantuan baik dari pemerintah maupun swasta serta secara swadaya melakukan pembesaran dan pengerasan jalan. Namun banyak jalan pedalaman mitra yang tidak dilengkapi dengan penerangan. Hal tersebut akan menyulitkan jika terjadi hal darurat seperti pencarian orang hilang, mengantar orang sakit, menghadiri acara pengajian, sholat jamaah di masjid dll. Tidak adanya penerangan jalan umum (PJU) dapat berisiko terperosoknya pengguna ke jurang karena akses jalan tersebut sudah tidak rata atau mengalami pengelupasan. Penambahan daya dan jaringan listrik untuk PJU diharapkan dapat diatasi dengan adanya sumber-sumber listrik alternatif baik tenaga air, angin maupun matahari. Kurva karakteristik Arus Tegangan sel surya memberikan informasi mengenai parameter dari sel surya. Temperatur, tingkat radiasi berpengaruh terhadap perubahan kurva karakteristik. Dengan mengetahui parameter keluaran dari sel surya, dilakukan penyusunan secara seri dan paralel sehingga mendapatkan output seperti yang diinginkan sebagai catu daya pada sistem 24 Volt.

Penelitian ini dikuatkan oleh penelitian sebelumnya yang dilakukan oleh Hasyim Asy'ari (2014) pemanfaatan sel surya dengan kapasitas 200 Wattpeak mampu menghasilkan energy listrik untuk mensuplai beban penerangan, rerata energy yang dimanfaatakan adalah 1027 Watt Jam atau 1,027 Kwh. Jatmiko (2012) menyatakan Selama pengujian berlangsung antara hari pertama sampai dengan hari keenam, intensitas cahaya matahari tertinggi terjadi pada hari pertama pengujian, pengambilan sampel pada jam antara 12.00 - 13.00 yaitu sebesar 115.800 Lux. Ilmar Ramadhan (2016) juga menyatakan berdasarkan Hasil pengujian modul surya (photovoltaic) terlihat bahwa hasil daya keluaran rata-rata mencapai 38,24 Watt,dan arus yang didapatkan sebesar 2,49 A (Ampere). Hal ini dikarenakan photovoltaic saat mengikuti arah pergerakan matahari akan selalu memposisikan photovoltaic untuk tetap menghadap matahari sehingga tetap akan dapat menangkap pancaran matahari secara maksimal. Kumara, N S (2010) menyatakan Informasi tentang ini diharapkan dapatdijadikan sebagai salah satu acuan cepat untuk mengetahui perkembangan PLTS di Indonesia khususnya bagi masyarakat yang tertarik untuk memanfaatkan tenaga matahari sebagai sumber pembangkit listrik sebagai partisipasi nyata dalam pengembangan pembangkit listrik ramah lingkungan dan berkelanjutan. Safrizal (2017) juga menyatakan PV Array membangkitkan energi listrik rata-rata harian 418,59 kWh melebihi konsumsi kWh beban. Hery Setyo Utomo (2017) menyatakan berdasarkan hasil penelitian menunjukkan dengan penambahan cermin teknologi reflektor pemindaian datar pada panel surya menyebabkan peningkatan arus dengan rata-rata - rata-rata 0,7533 ampere dan peningkatan nilai daya rata-rata 10,201 watt 
dibandingkan dengan tanpa menggunakan reflektor. Dengan melihat nilai efisiensi, panel surya yang menggunakan reflektor dengan teknologi scanning reflektor telah meningkatkan efisiensi dengan ratarata 6,362\%. Dafi Dzulfikara (2016) juga menyatakan Sel surya jenis monokristal (monocrystalline)merupakan panel yang paling efisien, menghasilkan daya listrik persatuan luas yang paling tinggi. Memiliki efisiensi sampai dengan 15\%.

Penelitian ini dilakukan dengan pengukuran arus dan tegangan pada sel surya tersebut di FMIPA UNJ. Dari hasil pengukuran diperoleh arus rata-rata tertinggi per hari sebesar 1,24 Ampere dengan tegangan rata-rata per hari sebesar 35,10 Volt serta daya rata-rata per hari sebesar 45,04 Watt. Dari data arus dan tegangan tersebut maka diketahui besarnya energi yang dihasilkan dan energi yang dapat disimpan dalam baterai. (Satwiko.S, 2012) Indonesia sebagai negara tropis mempunyai potensi energi surya yang tinggi dengan radiasi harian rata-rata (insolasi) sebesar 4,5 kWh/m2/hari (Solarex, 1996).

\section{Metode}

Berdasarkan masalah di atas yang belum terpecahkan yaitu daya dan jaringan listrik maka program pengabdian ini berfokus pada penambahan daya listrik pada mitra dengan cara memanfaatkan energi matahari. Selain itu, program ini diharapkan dapat menjaga keberlangsungan solusi tersebut di atas, tentunya dengan cara alih teknologi ke masyarakat mitra.

Agar program pengabdian tersebut terjamin terwujud dan terjamin pelaksanaannya maka dibutuhkan langkah langkah yang sistematis dan terukur. Berikut langkah-langkahnya: (1) Memetakan landscape mitra sasaran menggunakan map.google, (2) Penentuan jalan setapak dan fasilitas umum yang akan dipasang jalur kabel, (3) Penentuan jenis kabel untuk berbagai utilitas, (4) Penentuan lokasi yang layak untuk panel surya, aki, panel pengendali dan lampu penerangan jalan (setapak), (5) Pembuatan manual operation atau buku pentunjuk instalasi dan ekspansi jaringan, (6) Pelatihan instalasi dan ekspansi jaringan kepada minimal 10 peserta.

\section{Hasil dan pembahasan}

\section{Memetakan Landscape}

Lokasi mitra sasaran dipetakan dengan menggunakan map.google.com, hasil seperti gambar di bawah ini. Lanskap yang terjal berbukit-bukit disertai sungai alami dan tanah yang mudah bergeser berakibat pada sulitnya membangun peradaban yang layak. Semakin ke selatan ke arah mitra sasaran, maka semakin menuju bukit yang dinamai gunung Walat. Menuju mitra sasaran diperlukan tenaga ekstra karena jalan menanjak landai sampai puncak.

Dilihat dari langit, nampak relatif sedikit populasi yang ditandai berdirinya beberapa bangunan rumah yang tinggal disekitar sekolah. Bangunan sekolah yang semula tegak lurus menjadi sedikit miring karena pernah mengalami gempa tahun 2016.

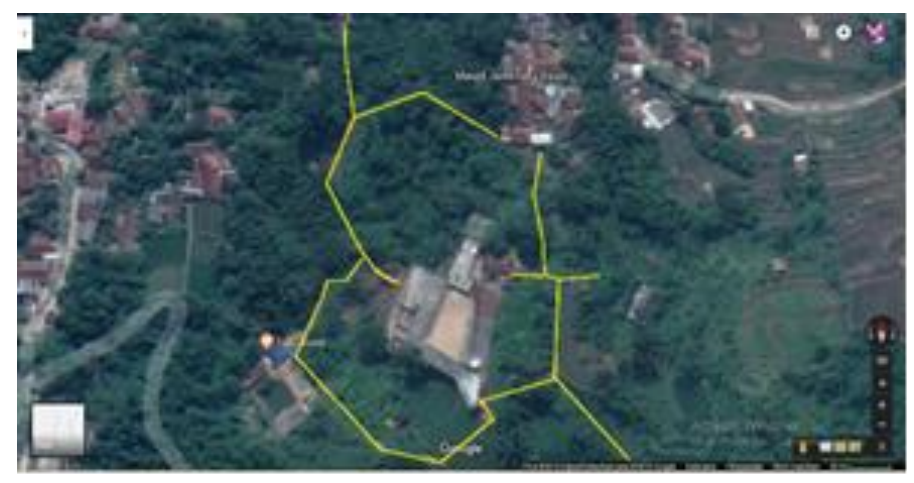

Gambar 2. Jalan Setapak

Jalan yang sering dilalui oleh masyarakat setempat yang akan dipasang jalur kabel pada gambar 2 yang diwarnai kuning. Rencana pemasangan total adalah 30 PJU yang berdampak pada semakin panjangnya kabel yang akan dipasang. Namun karena keterbatasan dana internal maka hanya terpasang 10 PJU. Sisa 20 PJU dan kekurangan kabel akan didanai dari mitra sasaran secara bertahap. Untuk itu program ini akan berlangsung seterusnya untuk mendampingi pemasangan PJU hingga mencapai 30 titik. 
Lokasi lain yang dipasangi penerangan yaitu ruang kelas di lantai bawah untuk sekolah dasar (ibtidaiyah) sejumlah 10 lokal. Mitra sasaran meminta agar lokal tersebut tetap diterangi agar mencegah aktifitas yang tidak diinginkan, paling tidak menerangi sepanjang teras lokal.

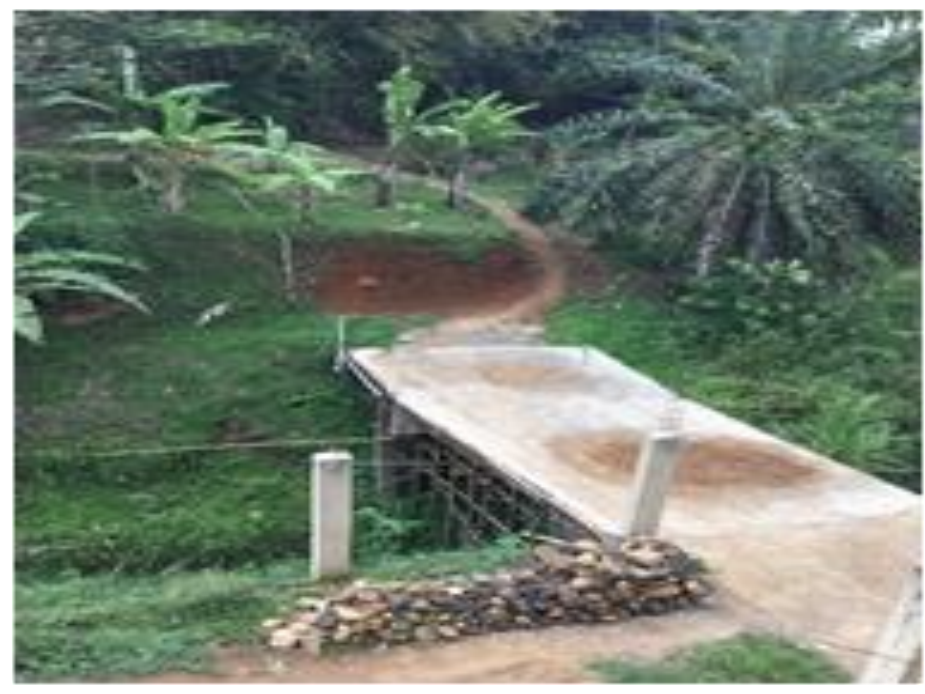

Gambar 3. Jalan Setapak depan Madrasah

\section{Penentuan Jenis Kabel Untuk Berbagai Utilitas}

Beban listrik yang digunakan pada tahap awal ini hanyalah untuk mensuplai Penerangan Jalan Umum (PJU) yang memiliki beban 18 watt tiap lampu. Untuk itu jenis kabel yang dibutuhkan berdiameter $1 \mathrm{~mm}$ berjenis serabut (NYAF). Tambahan kabel pada utilitas lain seperti 7 unit mesin jahit, penanak nasi dan seterika untuk para santri yang menginap (boarding school) akan dianggarkan oleh pihak mitra sasaran, karena utilitas itu mengkonsumsi Ampere yang sedikit lebih besar tetapi mempengaruhi kualitas kabel yang didanai program ini.

\section{Penentuan Lokasi Untuk Solar Cell System}

Panel surya, aki, dan Solar Charge Controller (SCC) semua diletakkan pada tanda kotak berwarna oranye seperti gambar 4 di atas

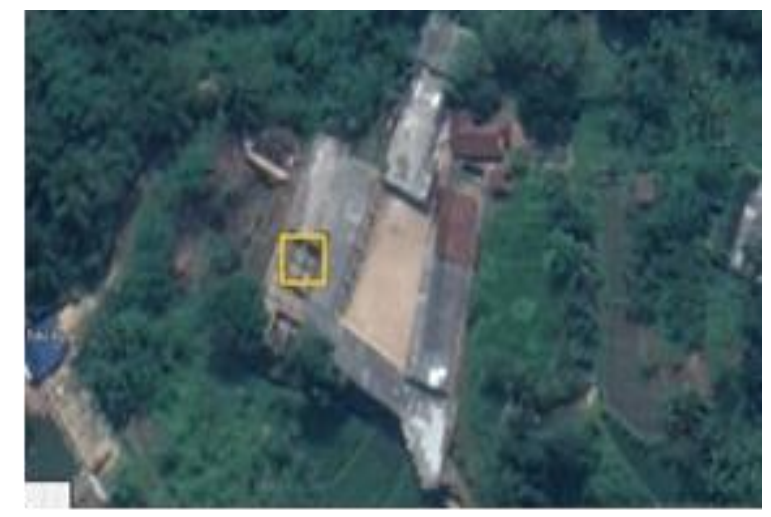

Gambar 4. Lokasi Solar

Kemudian peletakkan panel surya berada di atap lantai 2. Aki dan SCC diletakkan di ruangan kantor persis di bawah panel surya tersebut. Semua komponen itu diletakkan berdekatan agar meminimasi tegangan dan arus yang terbuang apabila kabel semakin panjang. 


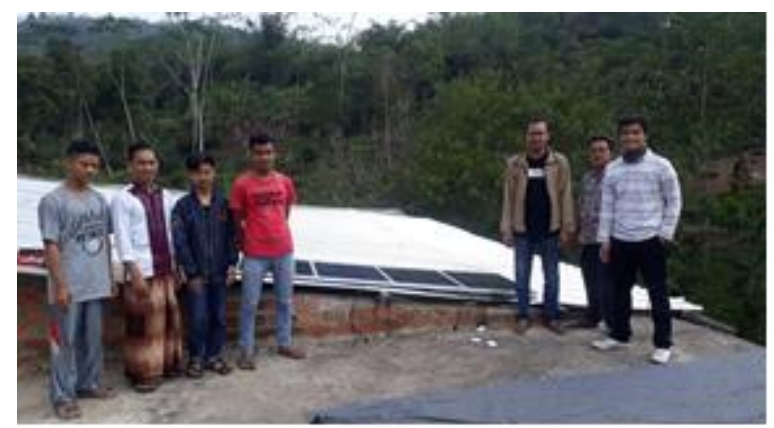

Gambar 5 Lokasi Peletakan Panel Surya

\section{Pembuatan Manual Operation}

Buku pentunjuk instalasi dan ekspansi jaringan masih dalam proses pembuatan selama program ini berlangsung sampai Oktober 2018. Materi buku petunjuk diambil dari berbagai panduan yang sudah termasuk dalam pembelian sistem ini. Panduan yang paling banyak ada pada SCC karena aki, panel-panel dan beban utilitas tergabung dalam SCC ini. Isi panduan ekspansi jaringan berisi tentang prinsip rangkaian seri dan paralel serta untung ruginya. Dan berisi panduan instalasi kabel ekspansi beserta asesorisnya.

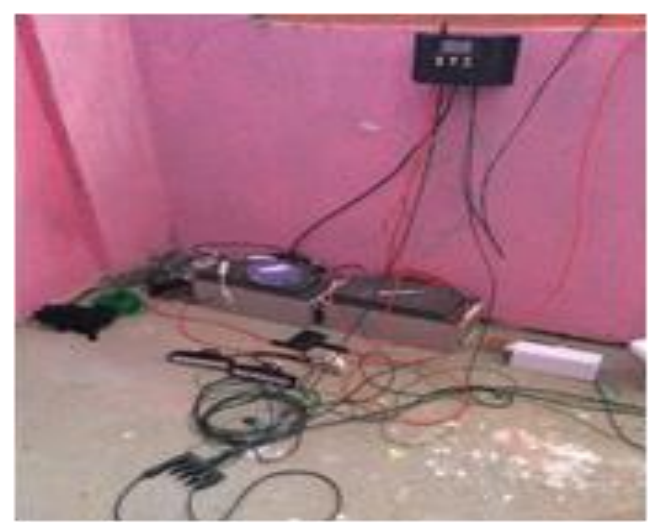

Gambar 6. Lokasi Aki dan Pengendali Daya (SCC)

\section{Pelatihan Instalasi Dan Ekspansi Jaringan}

Pelatihan instalasi sudah berjalan seiring dengan terpasangnya sistem panel surya ini. Pelatihan ekspansi jaringan dilaksanakan bulan Oktober minggu terakhir setelah buku panduan selesai keseluruhan dan tercetak 10 eksemplar.

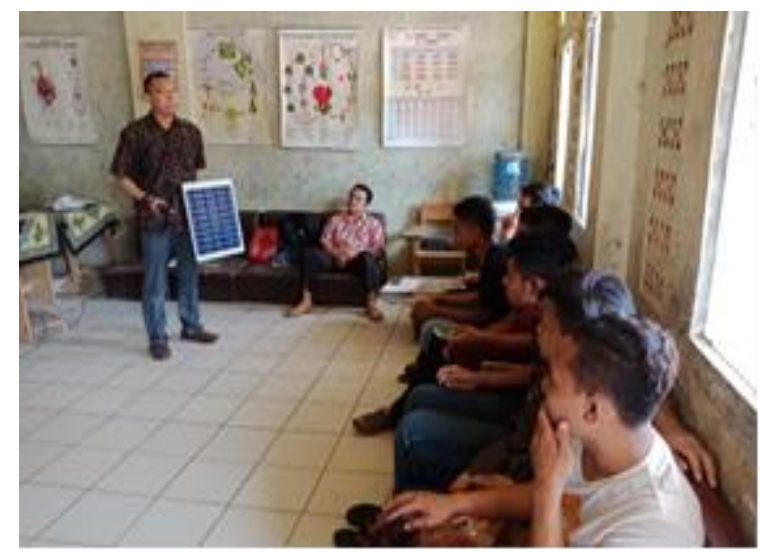

Gambar 7. Penyuluhan 


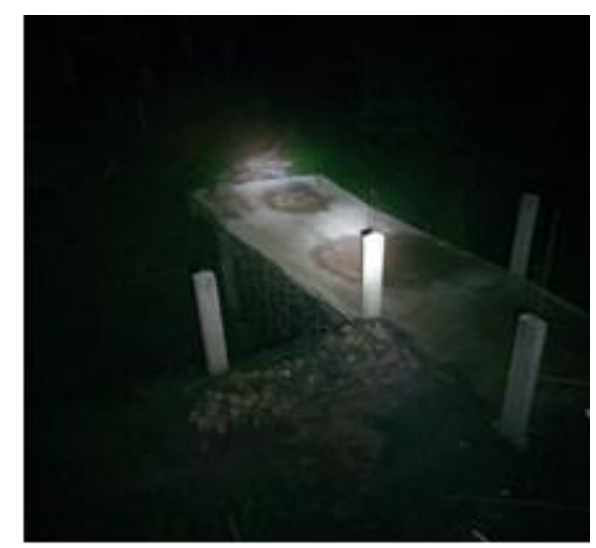

Gambar 8. Jalan Setapak yang diterangi Lampu Sorot

\section{Simpulan dan saran}

Berdasarkan wawancara, para santri merasakan manfaat PJU pada saat melakukan perjalanan keluar sekolah dalam rangka beribadah di masjid pada waktu isya dan subuh maupun membeli kebutuhan sehari-hari dimalam hari. Santri tidak perlu lagi menggunakan lampu pada handphone yang cahayanya relatif terang namun tidak menjamin kenyamanan perjalanan karena permukaan tanah tidak rata di sepanjang perjalanan pulang dan pergi.

Mereka cenderung lebih konsentrasi melihat ke bawah daripada melihat ke depan karena mereka mencari jalan yang rata tidak berbatu-batu sehingga sempat tidak sadar ada seseorang didepannya dari arah berlawanan. Selain jalan yang tidak rata, jalan ini juga berada di pinggir jurang yang mana belum ada pagar pengaman. Maka dengan adanya PJU ini untuk memperkecil kemungkinan pejalan kaki tersandung dan terperosok ke jurang maupun ke persawahan

\section{Daftar Rujukan}

Anwar Ilmar Ramadhan, Ery Diniardi, Sony Hari Mukti. 2016. Analisis Desain Sistem Pembangkit Listrik Tenaga Surya Kapasitas 50 WP. Jurnal Teknik Universitas Muhammadiyah Jakarta, 37 (2),

Bachtiar. M, 2006, Prosedur Perancangan Sistem Pembangkit Listrik Tenaga Surya Untuk Perumahan (Solar Home System), Jurnal SMARTek Vol 4, No 3.

Dafi Dzulfikara, Wisnu Broto. 2016. Optimalisasi Pemanfaatan Energi Listrik Tenaga Surya Skala Rumah Tangga. Prosiding Seminar Nasional Fisika (E-Journal). Volume V, Oktober.

Hasyim Asy'ari, Abdul Rozaq, Feri Setia Putra. 2014. Pemanfaatan Solar Cell Dengan Pln Sebagai Sumber Energi Listrik Rumah Tinggal. Jurnal Emitor Universitas Muhammadiyah Surakarta. Vol. 14 No. 01.

Hery Setyo Utomo, Triwahju Hardianto, Bambang S. K. 2017. Optimalisasi Daya dan Energi Listrik pada Panel Surya Polikristal Dengan Teknologi Scanning Reflektor. Jurnal BERKALA SAINSTEK Unej. V (1): 45-49.

Jatmiko, Angga. 2012. Intensitas Cahaya Matahari Terhadap Daya Keluaran Panel Sel Surya. Simposium Nasional RAPI XI FT UMS.

Kumara, N S (2010). Pembangkit Listrik Tenaga Surya Skala Rumah Tangga Urban Dan Ketersediaannya Di Indonesia. Jurnal Teknologi Elektro Unud. Vol. 9 No.1.

Lande, N. Malik. 2008. Solusi Komunikasi Bertenaga Matahari Aplikasi Fotovoltaik pada Base Transceiver Station, Jurnal Sains dan Teknologi Indonesia Vol 10 N0 3 Desember 2008 Hal 177-182. BPPT. 
Mintorogo. DS, 2000, Strategi Aplikasi Sel Surya (Photovoltaic Cells) Pada Perumahan Dan Bangunan Komersial, DIMENSI Journal of Architecture and Built Environtment, ISSN 2338-7858 (Online), Petra Surabaya.

Mixing solar panels - Dos and Don'ts - SOLAR PANEL SECRETS EXPOSED https://solarpanelsvenue.com/mixing-solar-panels/

Safrizal. 2017. Rancangan Panel Surya Sebagai Sumber Energi Listrik Pada Gedung Fakultas Sains Dan Teknologi Unisnu Jepara. Jurnal DISPROTEK UNISNU Jepara. Volume 8 Nomor 2.

Satwiko. S, 2012, Uji Karakteristik Sel Surya pada Sistem 24 Volt DC sebagai Catudaya pada Sistem Pembangkit Tenaga Hybrid, Prosiding Pertemuan Ilmiah XXVI HFI Jateng \& DIY, Purworejo 14 April 2012 ISSN: 0853-0823

Prasetyowati. R, 2012, Sel Surya Berbasis Titania Sebagai Sumber Energi Listrik Alternatif, Prosiding Seminar Nasional Penelitian, Pendidikan dan Penerapan MIPA, Fakultas MIPA, Universitas Negeri Yogyakarta, 2 Juni 2012 